DOI: $10.20472 / S S .2020 .9 .2 .003$

\title{
AN APPROACH TO THE CONTEXT OF THE MENTAL ILLNESS IN THE PENITENTIARY SYSTEM OF THE STATE OF TAMAULIPAS, MEXICO
}

\author{
JOSÉ LUIS CARPIO DOMÍNGUEZ, CYNTHIA MARISOL VARGAS OROZCO, \\ KARLA VILLARREAL SOTELO, MARÍA GUADALUPE MONTOYA COELLO
}

\begin{abstract}
:
The present study aims to deepen the prison context of the population diagnosed with psychiatric illness in the state of Tamaulipas, Mexico. A consultation was carried out at the state level in the databases of the Application of Sanctions Centers (CEDES) to identify this social group within the prison population, variables such as sex, age, time in prison, medical treatment, the breakdown of diagnosed psychiatric illnesses, visits and the legal situation within the criminal process. Finding that this group represents $1.1 \%$ of the prison population at the state level; the diagnosed psychiatric illnesses include: undefined psychosis (31\%), schizophrenia (20\%), paranoid schizophrenia (11\%), organic lesions (8\%) and depression (8\%), the prevalence of these illnesses was mostly diagnosed in prisoners between 30 and 60 years of age, where $28 \%$ also do not receive medication for their condition. In conclusion, the study recognizes this social group and its conditions of vulnerability within the prison system, so it is essential that public health policies in the country and the state of Tamaulipas must be oriented to meet the needs of these social groups in order to help guarantee the enjoyment of their fundamental rights.
\end{abstract}

\section{Keywords:}

prison, psychiatric disorders, disability, vulnerability

JEL Classification: I18, I14, K14

\author{
Authors: \\ JOSÉ LUIS CARPIO DOMÍNGUEZ, Autonomous University of Tamaulipas, Mexico, Email: \\ jcarpio@docentes.uat.edu.mx \\ CYNTHIA MARISOL VARGAS OROZCO, Autonomous University of Tamaulipas, Mexico, Email: \\ cmvargas@uat.edu.mx \\ KARLA VILLARREAL SOTELO, Autonomous University of Tamaulipas, Mexico, Email: \\ kvillar@uat.edu.mx \\ MARÍA GUADALUPE MONTOYA COELLO, Autonomous University of Tamaulipas, Mexico, Email: \\ mgmontoya@uat.edu.mx
}

\section{Citation:}

JOSÉ LUIS CARPIO DOMÍNGUEZ, CYNTHIA MARISOL VARGAS OROZCO, KARLA VILLARREAL SOTELO, MARÍA GUADALUPE MONTOYA COELLO (2020). An approach to the context of the mental illness in the penitentiary system of the state of Tamaulipas, Mexico. International Journal of Social Sciences, 
Vol. IX(2), pp. 40-65., 10.20472/SS.2020.9.2.003 


\section{INTRODUCTION}

The presence of mental illnesses in prisons represents a common social phenomenon in the state of Tamaulipas, and although the legal frameworks attend to the imputability of these people, in this phenomenon, various factors converge that favor the presence of persons deprived of liberty with psychiatric conditions within state prisons, and it is in these few studied factors which the present study focuses on. Mental illnesses are one of the subjects of least interest in prison studies in Mexico, however, understanding the medical, legal, family and social conditions institutionalized in the state's prison system allows for making this vulnerable group recognized within the context of the Application of Sanctions Centers (CEDES).

To contextualize mental illnesses as a public health problem it is necessary to mention that since 1959 the World Health Organization (WHO) in the Eighth Report of the Committee of Experts on Mental Health, presented the epidemiological problem of mental disorders. This emphasized the need to generate comprehensive and precise knowledge of prevalence and incidence data, as well as its origin (etiology) that guide public health policies towards prevention that these recommendations remain in force in the Sustainable Health Agenda for the Americas 2018-2030 and in the WHO Mental Health Action Plan 2013-2020.

The WHO estimates in their study on the Global Disease Burden of 1996 (Murray and López, 1996, cited in Zabala, 2016) that psychiatric pathologies will have an increase to $15 \%$ in the world population by 2020. And Zabala (2016) mentions that this percentage will exceed the total of cancer cases (Retolaza, 2007), therefore, the level of disability and reduction in the quality of life are becoming greater than chronic physical diseases (Alonso and Lépine, 2007), and the mental disorders will be the main cause of disability burden (Vos and Mathers, 2000), adding that more than $75 \%$ of the disease burden occurs in developing countries where the majority of people with psychiatric problems cannot access or receive inadequate treatment compared to patiens in developed countries (WHO, 2004).

Projections of an increase in pathological mental illnesses in the population represents a focus of attention for vulnerable populations particularly those who are in prisons in developing countries like Mexico, where despite the indications and recommendations of the Inter-American Commission of Human Rights, and the National Commission on Human Rights continue to manifest the phenomenon in penal institutions and remain in the shadow of other problems typical 
of the system. Problems such as insecurity, overcrowding and medical conditions like tuberculosis and sexually transmitted diseases.

According to the data of the National Security Commission of the Ministry of the Interior (2015) in Mexico, were detected 4476 persons deprived of liberty with mental illnesses, 1,054 are of them declared unimputable and 3,442 have psychosocial disabilities. The internment of psychosocial disability and those declared unimputable are found in state and federal prisons, highlighting the largest number in state-level centers, therefore, the National Human Rights Commission (2016a) has issued 69 Recommendations, a Recommendation General and 3 Special Reports highlighting the following observations (p. 20):

- Lack of a regulatory framework in accordance with international standards that allows granting reasonable adjustments or legal compensation measures applicable to this group, which makes them victims of abuse and discrimination,

- Absence of specialized personnel to provide technical attention,

- Inadequate classification according to the special and vulnerability characteristics of people with psycholocial disabilities, sometimes placing them in areas where people with infectiouscontagious diseases and where unhealthy conditions are present,

- Shortage of medicines, healing materials and medical equipment. And limiting access to basic services such as water, electricity and ventilation, in specific areas for the care and rehabilitation of prisoners with psychosocial disabilities,

- Lack of vigilance and control of situations for the coexistence of the psychosocially disabled with the rest of the internal population, which causes victimization, physical, sexual and psychological abuse,

- Lack of specific psychiatric treatment programs,

- Non-existence of clinical records, which prevent access to treatment consistent with their conditions aimed at their recovery, and which, in the case of those who have been found not guilty, violates the right to legal security, and a

- Inadequate control and monitoring to periodically assess the procedural status and where appropriation of the security measures are imposed.

It is necessary to mention that madness has traditionally been related to danger and this has conditioned the relationship between the mentally ill and modern society (Espinosa, 1997), making this group of indaviduals socially excluded. 
Therefore, the present study aims to understand the institutionalized medical, legal, family and social conditions in the state prison system to make this vulnerable group recognized within the context of the Sanctions Execution Centers in the state of Tamaulipas.

\section{Contextualizing the phenomenon in the Tamaulipas prison system}

The state of Tamaulipas has seven penitentiary centers, which are divided in two, according to the jurisdiction (state and federal), also called Application of Sanctions Centers (CEDES) and with the Preventive Prison of the municipality of Tula belonging to the state jurisdiction, while the Center Federal Readaptation No. 3 located in the municipality of Matamoros belongs to the federal jurisdiction (Table 1).

Table 1.- Cities and jurisdiction of the Penitentiary Centers of Tamaulipas, Mexico

\begin{tabular}{|c|c|c|}
\hline Name of the prison & Municipality & Jurisdiction \\
\hline $\begin{array}{l}\text { Centro de Ejecución de Sanciones Nuevo } \\
\text { Laredo (Nuevo Laredo Sanctions Enforcement } \\
\text { Center) }\end{array}$ & Nuevo Laredo & State \\
\hline $\begin{array}{l}\text { Centro de Ejecución de Sanciones Reynosa } \\
\text { (Reynosa Sanctions Enforcement Center) }\end{array}$ & Reynosa & State \\
\hline $\begin{array}{l}\text { Centro de Ejecución de Sanciones Matamoros } \\
\text { (Matamoros Sanctions Enforcement Center) }\end{array}$ & Matamoros & State \\
\hline $\begin{array}{l}\text { Centro Federal de Readaptación Social No. } 3 \\
\text { Noroeste (Northwestern Federal Center for } \\
\text { Social Rehabilitation No. 3) }\end{array}$ & Matamoros & Federal \\
\hline $\begin{array}{l}\text { Centro de Ejecución de Sanciones Victoria (City } \\
\text { of Victoria Sanctions Enforcement Center) }\end{array}$ & Ciudad Victoria & State \\
\hline $\begin{array}{l}\text { Centro de Ejecución de Sanciones Altamira } \\
\text { (Altamira Sanctions Enforcement Center) }\end{array}$ & Altamira & State \\
\hline $\begin{array}{l}\text { Reclusorio Preventivo de Tula (Tula Preventive } \\
\text { Prison) }\end{array}$ & Tula & State \\
\hline
\end{tabular}

Source: the authors.

One of the main problems that have affected the penitentiary system in Mexico is overpopulation. A reform of the country's criminal justice system was carried out in 2008, converting from an inquisitive justice system to an accusatory and adversarial one. This new system's objectives are to streamline the times of the criminal process and guarantee, based on the individual's innocence, that the criminal procedure seeks to avoid the preventive detention of individuals 
during the process through precautionary measures, seeking to avoid prison overcrowding. Although, one of the main deficiencies of the inquisitorial system was the times in which the defendants were sentenced, which caused people to be incarcerated in penitentiary centers awaiting trial for longer than an established court ordered sentence by a judge.

This reform to the justice system allowed to remedy those problems of the old system, however, two years before the transition to the new system, with the initiative of the presidency of the republic, began one of the most violent battles that has lasted until today, the fight against drug trafficking and organized crime.

During the mandate of the President Felipe Calderón Hinojosa (2006-2012) strategies were carried out to confront drug trafficking in Mexico, the so-called "war against drug trafficking" caused a considerable increase in the prison population nationwide, armed confrontations, security operations and surveillance in the streets of the country resulted in large-scale arrests of people involved in criminal groups and thus the overpopulation of both federal and state prisons (Correa, 2016).

This phenomenon of social, economic and political impact occupied a preponderant influence on the national agenda, where it was important to end organized crime at any cost, relegating other important aspects within the prison system such as self-governments, the needs of vulnerable groups, the training of personnel and the protection of the prisoners' human rights.

The state of Tamaulipas was no exception in terms of arrests and prison overpopulation (Figure 1), this was one of the main states affected by the fight against organized crime causing serious administrative issues, security and health problems in the penitentiary system. According to the National Human Rights Commission (CNDH) (2017), the state of Tamaulipas has a rating of 4.71 points out of 10 , in terms of the procurement and protection of prisoners' human rights derived from the problems caused by the self-government within these centers and scant attention to all prisoners by the centers' administrations. 
Figure 1.- Overpopulation in Tamaulipas penitentiary centers in the 2010-2016 period

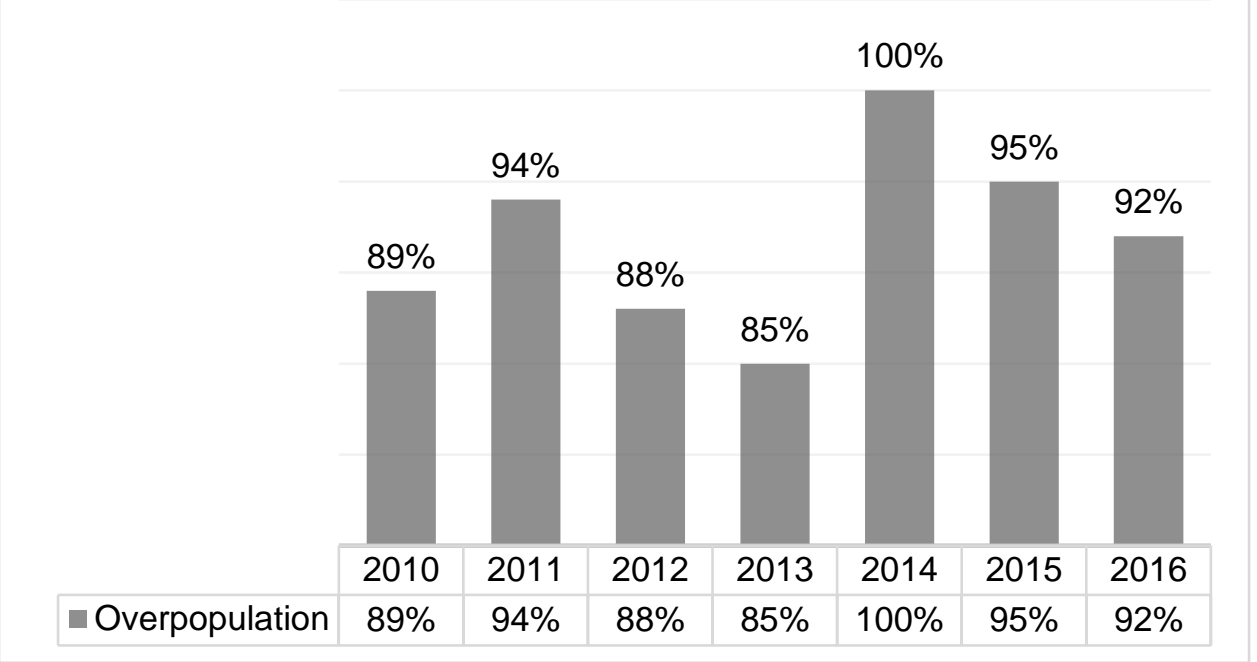

Source: Percentages calculated based on data obtained from the National Census of Government, Public Security and State Penitentiary System 2011 to 2017 (INEGI, 2017).

Currently the National Institute of Statistics and Geography (INEGI) the rate of persons deprived of liberty (PPL) in the state is 159 per 100 thousand inhabitants (INEGI, 2017) occupying the 14th place at the national level with the largest prison population, which translates into a population of 5473 people in the CEDES of state jurisdiction (INEGI, 2017, p. 13) (Figure 2).

Figure 2.- Rate* of persons deprived of liberty in prisons of state jurisdiction at the national level until 2017

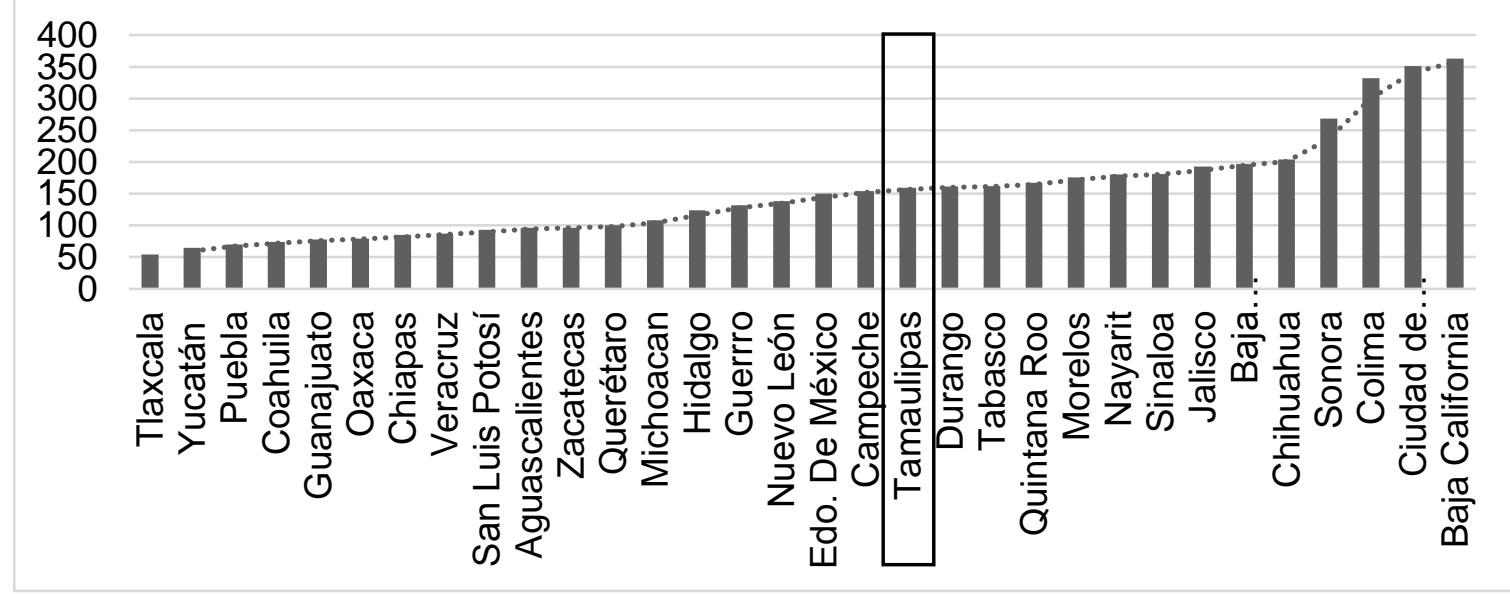

* The rate of persons deprived of liberty per 100,000 inhabitants is the result of the division of total persons deprived of liberty in a federative entity among its total population, multiplied by 100,000 .

Source: National Census of Government, Public Security and State Penitentiary System (2017) and National Population Council (CONAPO). Demographic indicators, 2010-2050. 
This context of national security in recent years allows us to understand the importance of making vulnerable groups recognized in state prisons, so that public policies are oriented to try and guarantee the protection of human rights and the needs of all persons deprived of liberty.

\section{Psychosocial disability and prison}

The World Health Organization (2013) establishes that psychosocial disability is that suffered by people with "diagnosis of mental disorder who have suffered the effects of negative social factors, such as stigma, discrimination and exclusion", therefore, they require special attention in prisons.

According to these estimates, $10.91 \%$ of the national prison population suffers from some psychosocial disability (Documenta, 2014), where at the national level 965 prisoners with some psychiatric diagnosis have been detected informally, including the unimputable population. However, this is not a problem exclusive to Mexico, according to the Center for Public Representation (CPR) (2013), it is estimated that in the United States that approximately 10\% of prisoners in prisons have some serious psychiatric condition such as schizophrenia, bipolar disorder or acute depression, while in England 39\% of the prison population has some psychosocial disability (Talbot, 2012) and in Spain 10\% of the prison population has some serious mental illness.

From the above mentioned statistics, two important aspects are evident in the study of mental illnesses in prisons: the lack of information on the magnitude of people with mental illnesses in prisons, and carrying out evaluations of persons deprived of liberty to diagnose possible ailments and receive adequate care (Documenta, 2014, p.3).

\section{The legal framework of psychiatric prisoners}

To understand the relationship between the mentally ill and prisons from the Mexican legal perspective, it is necessary to differentiate unimputable people from those who can be given a custodial sentence. For this, article 15 section VII of the Federal Criminal Code establishes that the causes of exclusion of crime when:

At the time of performing the typical act, the offender does not have the ability to understand the illegal nature of the offence or to behave in accordance with that understanding, by virtue of suffering from mental disorder or defective intellectual development, unless the offender has displayed mental disorder under false pretenses, in 
which case it will respond for the typical result as long as it has been foreseen or predictable (Art. 15, section VII).

Therefore, it can be established that the individuals who, during the imposition of the sentence, were declared unimputable are those who at the time of committing the offense did not understand the illicit nature of their actions, so they cannot be deprived of liberty; while those who entered the prison and once inside were diagnosed or developed a disability, whether for substance abuse, beatings, etc., in which they can be assigned a legal penalty according to the crime committed.

The Law on the Execution of Private and Restrictive Sanctions of Freedom of the State of Tamaulipas (2012) in article 78, section III, establishes that:

The respective Penitentiary Counselor must go at least once a month, at random, to the establishments where the sentenced receive education, training or work and professional specialization, therapeutic treatment against addictions and physical or mental illnesses, to take direct knowledge of the compliance with the penalties and measures imposed, recording their progress and informing the Council, as well as cases of non-compliance, and for the same purposes, may establish communication with the family of the sentenced (p. 17).

In the Mexican legal system there is the therapeutic justice program. Which is a benefit of the replacement of the execution of the penalty determined by the Execution Judge, for patrimonial crimes without violence, whose purpose is to promote the rehabilitation and integration of sentenced persons related to substance abuse, under the supervision of the sentencing Judge, to achieve the reduction of crime rates.

The National Law of Criminal Enforcement (2016) in Article 79 established as Therapeutic Measures that when the diagnosis of the medical services area reveals the need to apply therapeutic measures that imply a risk to the life or physical integrity of the person deprived of their freedom. The written consent of the same will be required except in cases of emergency and in those that attempt against its integrity. The competent prison authority may determine it if the person deprived of his liberty is not in a position to grant his consent. He may be required to his spouse, ascending or descending relative, or to the person previously designated by him. In case of not having any consent, it will be the responsibility of the competent Penitentiary Authority to determine what is conducive. 
The Criminal Code for the State of Tamaulipas in article 35 in section I and II establishes that it is considered as unimputable to:

II.- Who, at the time of the conduct of intellectual disability, or due to hearing and speech impairment, lacks the ability to understand the illicit nature of the act or to be determined in accordance with that understanding;

III.- Who, at the time of the action or omission, is in a state of unconsciousness of their actions, determined by the accidental and involuntary use of toxic and intoxicating and/or narcotic substances, by an acute toxinfectious state, or by an involuntary intellectual disability of pathological and transitory nature. Unless the disturbance of conscience has been caused by the agent to facilitate the realization of the fact to procure an excuse, in which case the sanction will be aggravated up to a third more than the judge would have imposed by unknown factors.

The Law on the Execution of Private and Restrictive Sanctions of Freedom of the State of Tamaulipas (2012), in article 11 establishes that:

Mentally ill, infectious, highly dangerous or addicted to illegal substances, will be attended by specialized personnel and will ensure that their detention is in special sections enabled inside the Centers.

\section{The mentally ill in prison and human rights}

The report "Situation of people with psychosocial disabilities and imputability in the penitentiary centers of Mexico" carried out by the National Human Rights Commission in 2016, in national and international regulations, establishes that people with these types of problems require attention according to their specific characteristics. Characteristics which limit their ability to conduct themselves independently. So it has been recognized that their attention implies providing the necessary conditions that favor the regulatory adjustments of operation and infrastructure that allows to achieve an optimal level of operation and reduction of its limitations for its daily life. At the same time avoiding its discrimination and vulnerability.

One of the reasons why there are so many irregularities in the prison system, in relation to people with mental illnesses, is because people suffering from mental disorders who are incarcerated may or may not have total knowledge of the reality attributed to them. 
In the pronouncement called "Right to the Protection of the Health of Internal Persons in Prison Centers of the Mexican Republic" issued by the CNDH (2016b), it states that since 2004, mental illnesses were taken in prison as a problem for both prisons and public health.

Prisoners with diseases, including mentally ill men and women, are not treated in a timely manner, nor are there promotional activities for health prevention for infectious-contagious diseases, chronic degenerative, oral diseases and treatment of addictions (CNDH, 2016b, p. 16).

\section{Studies related to the mentally ill in the prison system}

Once inside prisons, mentally ill patients should have an adequate medical evaluation; Chamizo (1997) makes reference that once the prisoner enters the prison, as a preventive or compliance with sentence, he is subjected to an admission protocol and a health check. This is where they detect weather or not the prisoner displays signs of mental illness. Depending on the severity and the mood in which the prisoner is in various measures are taken. The mentally ill prisoners are kept for a few days in nursing for observation and if a disease is detected the pharmacological treatment is indicated.

In addition, Hernández and Espinosa (2000) mention that psychiatric care in prisons must be constituted through primary care. Which should be composed of doctors, nurses and trained auxiliary personnel, with psychiatry remaining in the second level. This primary care should initially attend to the prisoner/patient and attend to resolve most of the mental health problems that occur in prison. This is done to avoid "psychiatrizing" the patient with drugs that may or may not need so immediate action.

When analyzing the question about why there are so many mentally ill persons in prison, some studies allows to know this phenomenon. Martínez (2004) argues that the main reasons why prisoners are found with psychiatric problems in prison can be for these three reasons: a.) cases of inadvertent alienation; b.) alienation warned but not appreciated as a cause of unimputability and c.) alienation acquired. The author finds that "the absence of guardianship structures of the mentally ill. Which prevents the representation and attention to the interests of the infringing patients, and leaves them in a position to deal with legal uncertainty and ineffective protection of their constitutional rights" (Martínez, 2004, p. 98). Which allows an approach to the unprotected situation the mentally ill encounter within the institution. 
Conde and López (2009) argue that social reintegration as the end of the main prison system can be complicated when it comes to mental patients, and in addition to the stigma generated by having faced a criminal process. Having a mental disability and dealing with the constant antagonism being in prison, an ideal therapeutic space to attend to psychiatric patients is imperative for their mental health.

Therefore, this study aims to know the prison context of the population with a psychiatric diagnosis and the contexts of their internment within the State and Federal Application of Sanctions Centers in the state of Tamaulipas, Mexico.

\section{METODOLOGY}

\section{Data access}

To understand the prison context of persons deprived of liberty that have been diagnosed with a psychiatric disorder, a request was made and addressed to the Subsecretary for the Application of Sanctions and Social Reinsertion of the state of Tamaulipas, to access the information required for the study. All information related to the state CEDES is concentrated. The information was not up to date about prisoners diagnosed with any psychiatric illnesses until 2019, it was necessary to request through this institution that all current prisons in the state consider the recent data of the study population. Which brought double benefits which allowed access to the data for the study and was useful for the Subsecretary to update the information.

\section{Description of research techniques}

In the analysis of the information related to the study group two techniques were used. Statistical inference and participant observation. For the statistical analysis, due to the study population being small (61 prisoners), Excel was used to process and analyze the data. At the same time the participant observation was used to know the spaces and the context in which these people live inside the prison.

Statistical inference as an analysis technique allows to describe and analyze groups of data to obtain inferences from a study sample and thus obtain conclusions of interest (Faraldo, 2013) in the study. Were analyzed qualitative variables such as sex, age, type of analysis, diagnosed mental illness, crimes for which they are in a criminal process. Visits by relatives in the 
municipality where the CEDES are with this population and the presence of other diseases in the study group.

Participant observation consists in systematically observing what happens in certain contexts, situations or spaces to identify phenomena of interest for a study (Guber, 2001). This technique was used to strengthen the information analyzed by statistical inference; so visits were made to the CEDES to inspect the spaces and the context in which these people live inside the prison and through a field diary in which notes were taken on data of interest for the study. Like the activities that are carried out within the spaces for psychiatric prisoners such as painting and drawing workshops, crafts, etc.

The present study is attached to the ethical guidelines for research in social sciences defined by the Code of Ethics of the International Sociological Association (ISA) (2001).

\section{RESULTS AND DISCUSSION}

\section{General data found}

In the present study it was found that persons deprived of liberty with a psychiatric diagnosis in the state prisons of Tamaulipas, represent 1.1\% (61 cases) of the total prison population and although the percentage is not high, it allows to identify the existence of people with mental illnesses in this context. During the study it was identified that $95 \%$ of this population are men, while only $5 \%$ are women, the average age is 39.9 years of age (Figure 3 ) the lowest age is 23 years and the oldest is 69 years old.

The CEDES of the state have spaces allocated to these people as established in article 11 of the Law on the Application of Private and Restrictive Sanctions of Freedom of the State of Tamaulipas (2012). Which depend on the spaces available in each center, however, considerable progress has been made in the last 5 years, including medical check-ups, recreation activities, the visit of a psychiatrist to evaluate them and prescribe medications. And importantly the allocation of an exclusive space for them separated from the rest of the prison population. 
Figure 3.- Age range in people diagnosed with psychiatric illnesses in the CEDES of Tamaulipas, México.

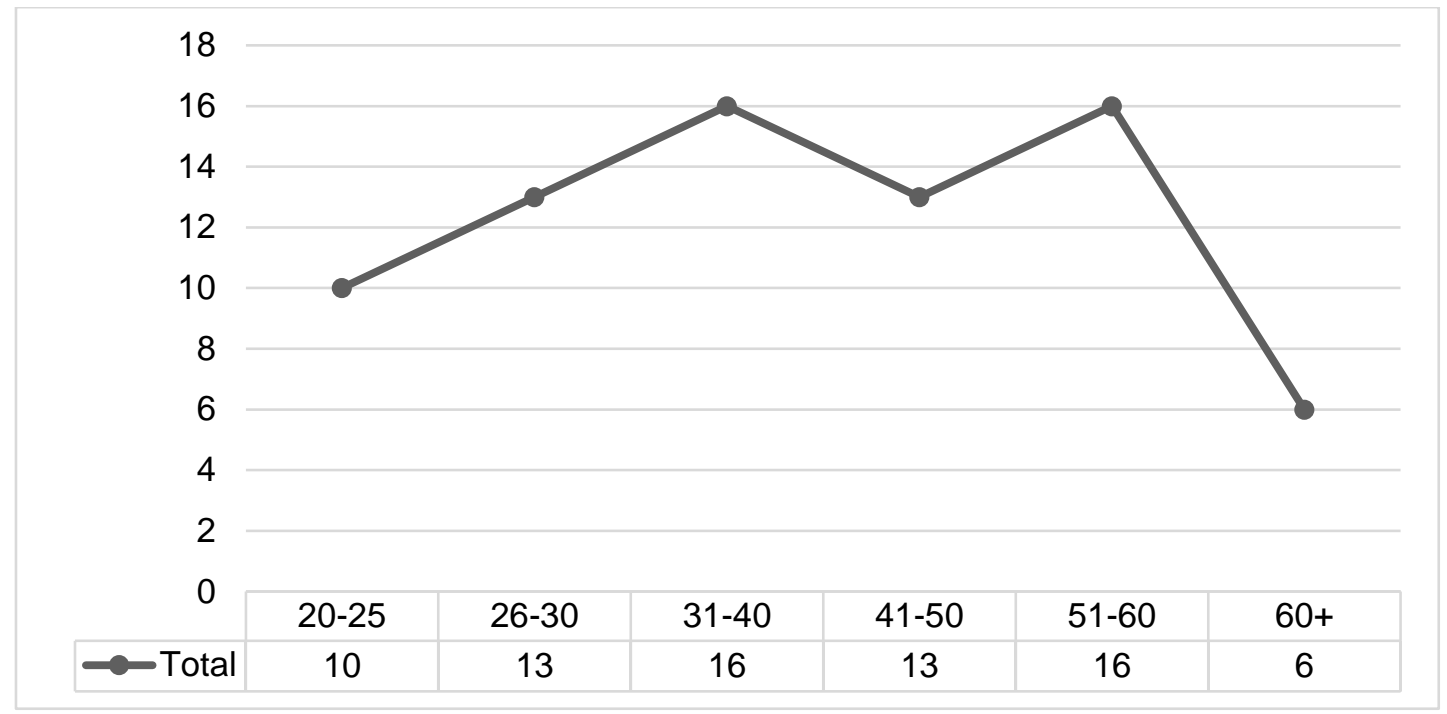

Source: the authors with information provided by the Subsecretary of Execution of Sanctions and Social Reinsertion of the state of Tamaulipas, México

The CEDES do not have a psychiatrist in their workers' plant. Which has resulted in the psychologists and social workers of the Technical Council of the CEDES carrying out most of the attention to this social group within the prison that derived from a high number of prisoners. It reduces the quantity and quality of the attention towards this group that requires special attention. This lack of attention is due to the Technical Council that has to attend all the prisoners of the penitentiary center and not only those with disabilities.

In addition to the lack of a psychiatrist and the lack of personnel to meet the needs of these people was identified. In 4 of the 6 centers other prisoners (not psychiatric) are responsible for the care and attention required by the psychiatric prisoners as part of prison work and who, in technical terms, are not trained to take care of people with special needs.

\section{Diagnosed disorders}

In the psychoanalysis, diseases can be classified into two types: psychosis and neurosis. Within the psychosis, prisoners were found with bipolarity, manic depression, schizoafective dirsorder, dementia, paranoid schizophrenia, depression and schizophrenia. In the neuroses were found: with borderline disorder and intellectual disability.

Mental illnesses diagnosed by psychiatrists in the CEDES of Tamaulipas, are: unspecified psychosis $(31 \%)$, schizophrenia $(20 \%)$, paranoid schizophrenia $(11 \%)$, depression, intellectual 
disability and brain injuries with $8 \%$ of percentage representation each one (Figure 4), in the analysis general parameters of the diseases were not evaluated associations such as acute, moderate, severe, mild, etc., with the aim of making visible the heterogeneity of the principal diagnostics.

Figure 4.- Psychiatric illnesses diagnosed in prisons of Tamaulipas, México in 2019*

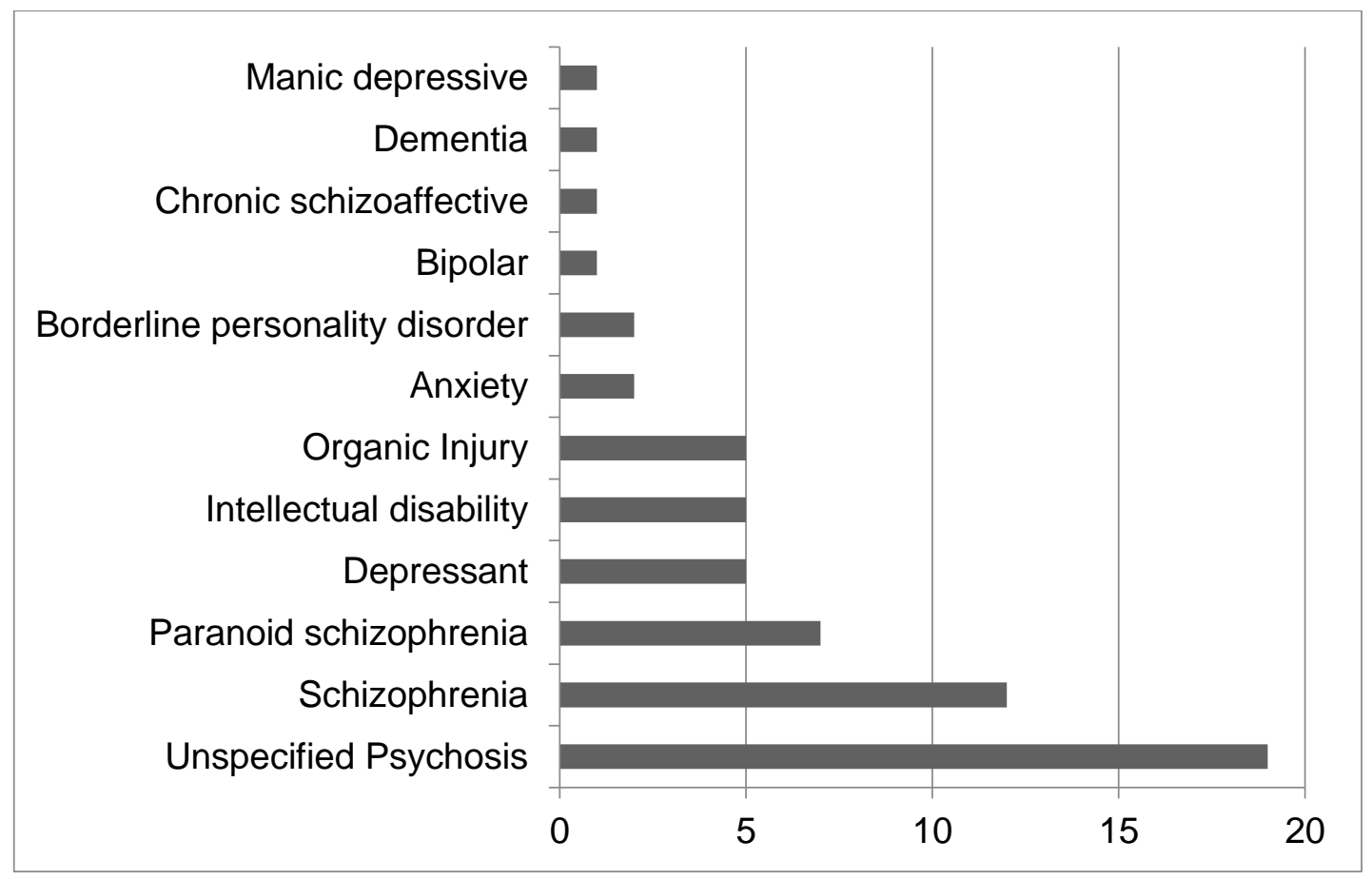

Source: the authors, with information provided by the Subsecretary of Execution of Sanctions and Social Reinsertion of the state of Tamaulipas, México

The Figure 4 shows that cases of unspecified psychosis were diagnosed in 19 people (31\%). Psychosis is defined as a mental disorder that affects the person's ability to be in contact with reality. The Early Psychosis Prevention and Intervention Center (EPPIC) (2006) establishes that the symptoms of psychosis include mood swings and the presence of abnormal ideas, confusing thoughts, hallucinations and delusions. Psychosis can be caused by drug abuse (Benavides et al, 2019), organic damage or a delusional disorder; in this study, only two prisoners were identified with this diagnosis after drug abuse, in others the origin remains unknown.

Among the psychotic disorders is schizophrenia, which is characterized as a distortion of thought, perceptions, emotions, language, consciousness and behavior (WHO, 2019) and has been one of the most studied mental illnesses in prisons. Studies on prisoners with ezquizophrenia mention that in France it comprises 6.5\%, Autralia between 4 and 4\%, Iran estimates 3.9\%, United States 
with 2.7\%, United Kingdom between 4 and 5\% and Spain with 4\% (Fuentes and Fernández, 2016). In the case of Tamaulipas prisons, a diagnosis of $20 \%$ with ezchizophrenia and $11 \%$ with paranoid ezchizophrenia was found among the study population.

About neuroses, two prisoners were diagnosed with borderline personality disorder and 5 with intellectual disability. Which represent $3 \%$ and $8 \%$ respectively in relation to the total cases of mental illnesses diagnosed in Tamaulipas CEDES. Borderline personality disorder is characterized by impulsive and often dangerous behavior with suicidal tendencies, self-mutilation and dissociation. Problems to control anger and paranoid thoughts related to stress (National Institute of Mental Health, 2010). The intellectual disability is a state of cognitive functioning significantly lower than normal for the person's age. It is characterized by significant limitations both in intellectual functioning and in its adaptive behavior, whether conceptual, social and practical (Schalock et al, 2010).

The study identified 5 prisoners with depression at $8 \%$ representation of the total diagnoses. Depression is characterized by the presence of sadness, loss of interest, feelings of guilt or lack of self-esteem, sleep disorders, and feeling tired. Depression in its most serious form can lead to suicide (WHO, 2017) and although it is one of the most common disorders within prisons, it is closely linked to the prison confinement process and the factors that derive from it, including the use of drugs or alcohol (Colmenares et al, 2007; Uribe, Martínez \& Lopez, 2012). Although depressive episodes in the prison population are common, those that were evaluated for the present study are those that have prolonged episodes of depression and that need medication and due to the condition were separated from the rest of the prison population.

Organic damages contemplated in Figure 4 include those conditions related to drug use that have affected the prisoner's ability to have a normal life and face the process of social rehabilitation offered by the CEDES. People diagnosed with Organic damage represents $8 \%$ of the total diagnoses with a total of 5 people who are in the designated area for psychiatric patients within the prison to safeguard their physical integrity and adequate care.

\section{About psychiatric treatment}

The study identified that $28 \%$ of this population does not receive medication for their disease. While $72 \%$ of those who do receive it depend on the financial budgets of CEDES and the availability of the medicines in local pharmacies and hospitals, however, this is not always the case and it is the prisoner's family who seeks to get the medicine when it is not provided by the 
institution. Which becomes a challenge for poor families due to the costs of the medical treatment.

The CEDES of Ciudad Victoria, has the largest number of prisoners with a psychiatric diagnosis who do not receive medication. Followed by that of the cities of Reynosa, Altamira and Matamoros, so in 4 of the 6 prisons in the state there are people who need medication and do not have access to it by any of the factors mentioned above (Figure 5). This situation can lead to the fact that the symptoms of each disease are exacerbated with serious consequences for prisoners, their companions and people in charge of caring for them.

Figure 5.- Supply of medication to persons diagnosed with psychiatric illnesses in the Tamaulipas prison centers in 2019

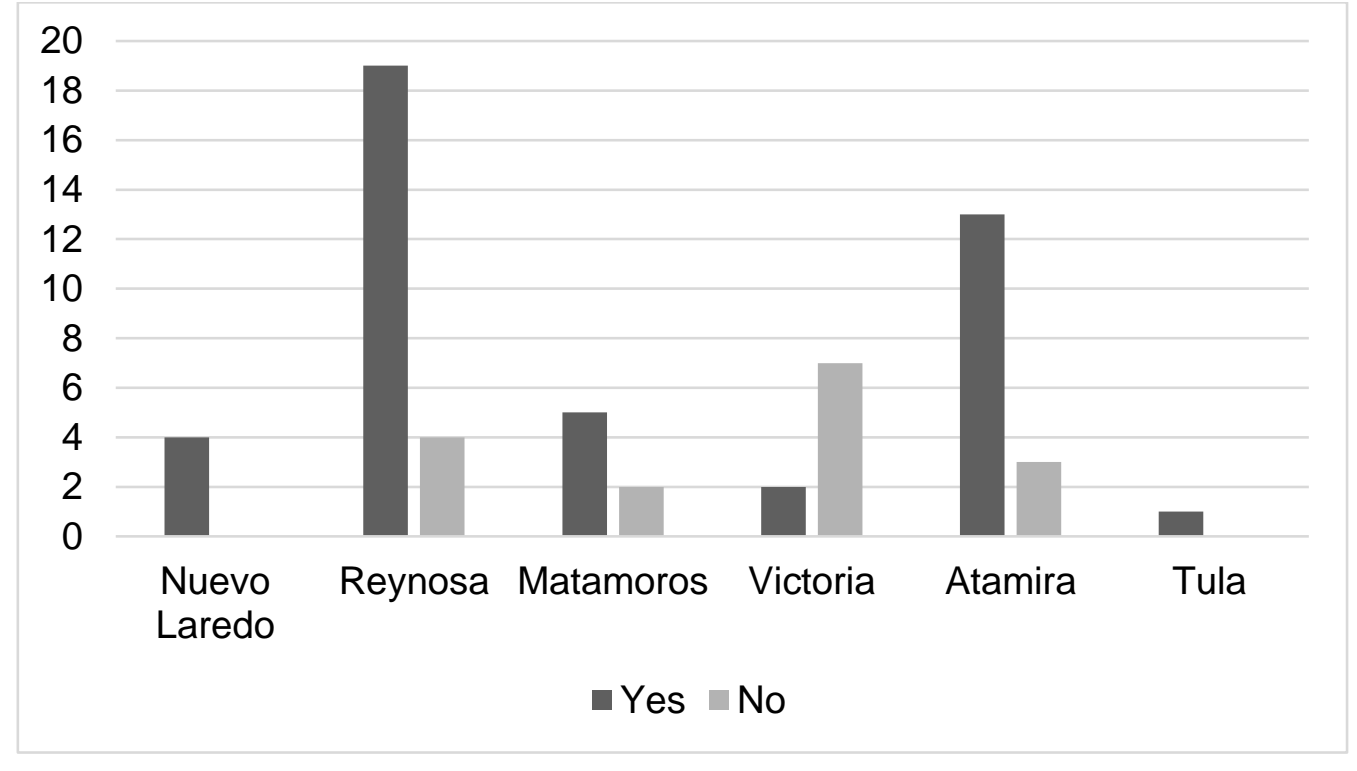

Source: the authors with information provided by the Subsecretary of Execution of Sanctions and Social Reinsertion of the state of Tamaulipas, México

This situation has already been presented previously, in the CEDES of Reynosa, a patient with a diagnosis of schizophrenia, almost asphyxiated the person in charge of caring for them (another non-psychiatric prisoner). Which put the administration on alert about the urgency of medications to guarantee security of all. So that CEDES requests the most frequent visit of the only two psychiatrists who attend this prison population in the northern area of the state that encompasses the CEDES of Nuevo Laredo, Reynosa, Matamoros and the Federal Readaptation Center Social No. 3 Northwest in Matamoros. 
The existing discussion on the administration of medication to all those diagnosed with psychiatric illnesses lies in what Hernández and Espinosa (2000) define as "psychiatrizing" the mentally ill, this term refers to the administration of medication immediately and without constant adequate assessment, so they propose a "primary care by doctors, nurses and trained staff", however, this proposal cannot be carried out in prison overpopulation contexts.

However, the present study coincides with Igoumenou, Kallis and Coid (2015) when they establish that the medication must be accompanied by the medical follow-up of psychiatrists. The timely identification of mental disorders allows to improve the living conditions of the prisoners and the safety of the other prisoners and of those in charge of caring for them.

\section{Other diseases diagnosed in psychiatric prisoners}

Other diseases that affect psychiatric prisoners were considered in the present study, due to diseases in prisons that tend to have a high record of cases (México Evalúa, 2012), and perceptions about the quality of health services by prisoners are generally negative (Azaola, 2007). According to the National Human Rights Commission (CNDH) (2016b), the general conditions in which the prison system is currently in the Mexican Republic, have resulted from insufficient resources financial, human, material and facilities in order to offer a quality comprehensive service to people who are deprived of liberty (p. 5).

In the study group there were two cases of psychiatric prisoners diagnosed with diabetes mellitus and loss of limbs and organs such as eyes and fingers. These two cases also occur in people aged 67 and 69 with a diagnosis of psychosis and demensia respectively. However, both cases are under medical treatment by the institution and the family.

\section{Legal situation of psychiatric prisoners in the Tamaulipas CEDES}

About the legal situation of psychiatric prisoners, it is necessary to previously explain that in the inquisitive justice system (which was valid until 2016 in Tamaulipas) the legal situation of prisoners in the state could be classified into three stages: processed, sentenced and in execution (application of the sentence).

In the stage of prosecution the order of formal prison or deprivation of liberty is given and the criminal investigation phase is initiated to gather the evidence that will be presented at the trial. However, criticisms of this justice system are that they focused on the waiting times at this stage. Since many times they exceeded the time established by the sentence of the crime. In other 
words they waited for the trial date more years than those that would be assigned a sentence. In the second stage, called "sentenced", the prisoner has already been found guilty in court, however, the sentence has not been "ratified", which allows the prisoner to formulate a legal protection or request and a review of the case. Which may result in a greater or lesser number of years for a sentence Finally, the stage of execution (application of the sentence). At this stage the prisoner is serving the sentence issued by the judge. Once that has been ratified that translates as the final sentence of the imprisonment for the time that the law determines.

Once this was clarified, in the CEDES of the state of Tamaulipas it was found that $46 \%$ of the psychiatric prisoners are in the stage of execution or application of the sentence, $33 \%$ in prosecution and $21 \%$ in sentenced. Therefore, more than half of the psychiatric prisoners are waiting for their sentence to be ratified so that they can comply with the times stipulated by the law (Figure 6).

Figure 6.- Legal situation of prisoners diagnosed with psychiatric illnesses in Tamaulipas penitentiaries

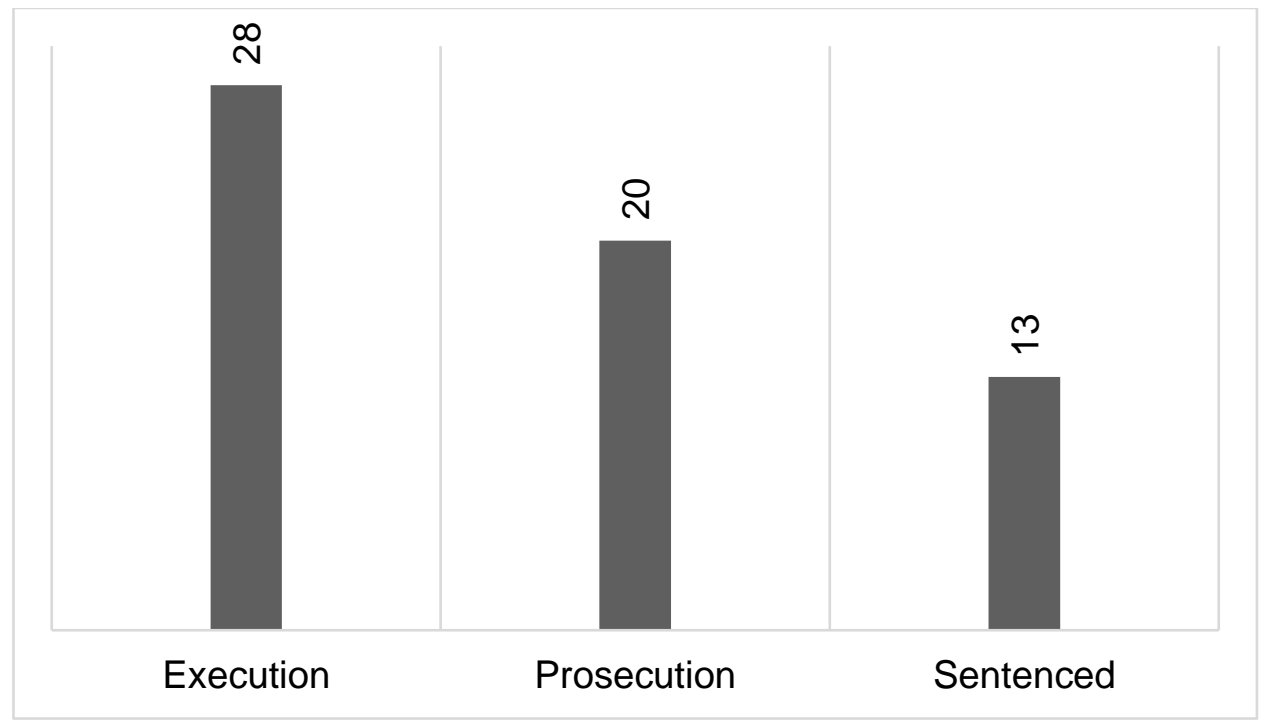

Source: the authors with information provided by the Subsecretary of Execution of Sanctions and Social Reinsertion of the state of Tamaulipas, México

However, this situation is not rare to the prison context of the country. Studies have found that prisoners who have been provided with a lawyer by the State (public defender) are less likely to expedite the criminal process and access prompt justice. In the worst case scenario a fair defense (Carpio, Vargas \& Villarreal, 2017b). 
Psychiatric prisoners are at a disadvantage compared to the rest of the prisoners due to the conditions of their illness. In many cases it makes it impossible for them to access adequate legal representation, coupled with the saturation of cases and neglect by public defenders. This situation of legal vulnerability violates the rights of prisoners to access legal services according to their needs.

\section{Penitentiary visits to psychiatric prisoners}

The study identified that $46 \%$ of these groups within the state's CEDES do not receive visits from friends or family. Although visits play a fundamental role in the rehabilitation and quality of life processes of prisoners (Cerda, 2014; Villarreal, 2016; Carpio et al, 2017a). The absence of visits can favor the presence of mental illness such as depression and psychosis. So that social support networks and preventive actions can contribute to improving the quality of life and health of prisoners (Benavides et al, 2019).

The CEDES of the municipalities of Reynosa and Victoria, are the centers in which psychiatric prisoners receive more visits from family members (Figure 7 ). In the space allocated to this population in the CEDES of the city of Reynosa has a recreation area within which is used for visits.

Figure 7.- Visits by families and friends to prisoners diagnosed with psychiatric diseasess in the CEDES of Tamaulipas

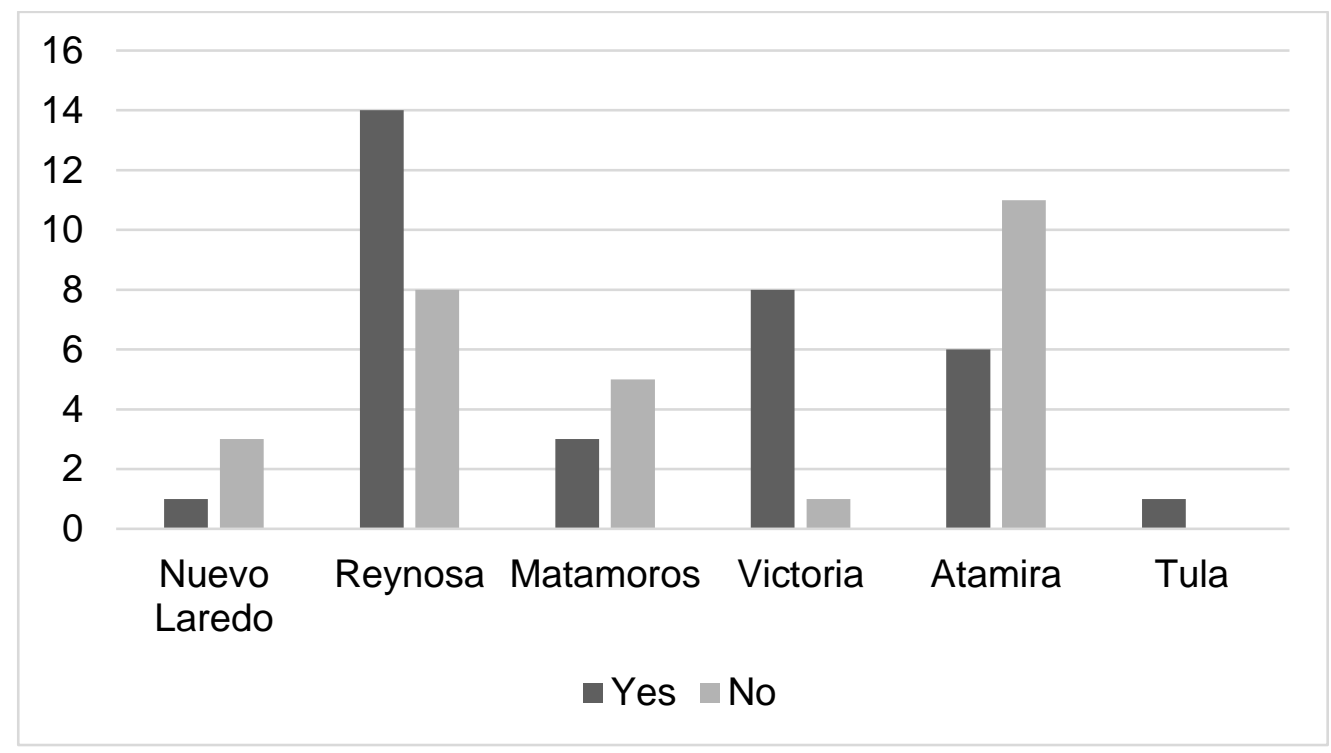

Source: the authors with information provided by the Subsecretary of Execution of Sanctions and Social Reinsertion of the state of Tamaulipas, México 
Visits are allowed twice a week. This allows families to be in continuous contact with their relatives within the prison. However, in the case of psychiatric prisoners, the prison has become a place where relatives forget about them under the discourse that they are in a safer place than on the street and do not represent an extra economic expense for the family.

\section{Women in prison with a psychiatric diagnosis}

In a gender perspective the population of women who have been diagnosed with a psychiatric condition is coincident with the total prison population at the state level where the female population represents $5 \%$ of the total prisoners in the state, however, it becomes relevant in the present study due to women in prisons live in conditions different from the male population.

Women are more vulnerable than men in the prison context. These institutions do not promote programs for their improvement. The CEDES lack of transformative programs regarding education and the access for women to sources to earn money inside prison is limited compared to the male population (Villarreal, 2016). In this scenario women who have been diagnosed with a mental illness, in addition to suffering from the limitations of the prison system, are found in more vulnerability conditions than the rest of the women due to their psychosocial disability.

The study identified that women in this group in Tamaulipas prisons suffer from paranoid schizophrenia (2) and depression (1), with an average age of 35 years. The crimes for which they are in prison are: carrying firearms for the exclusive use of the army, homicide and filicide. Regarding legal process, these women are: two in prosecution and one in execution of the sentence.

Women who are in prisons have limitations in relation to access to job sources and education within the CEDES. However, it was found during the study that women with psychiatric illnesses are at more disadvantage than the others due to the fact that they need to receive medication that often the medical area of CEDES does not have. Therefore, they depend on their family outside of prison and in poverty scenarios that limit their ability to access medications because of high cost. Which aggravates the symptoms disease and consequently reduces the quality of life of women in prison and reduces the ability to access to the few job opportunities inside the prison. 


\section{CONCLUTIONS}

In conclusion, the psychiatric population within the prisons of the state of Tamaulipas represents a minority with respect to the total number of prisoners in the state. In this approximate study of the context of this social group. It is highlighted that the situations of vulnerability experienced by the mentally ill experience in these prisons is the lack of access to specialized medications to treat their disease. This is due to four of the six centers where psychiatric prisoners who are not medicated. Another aspect is the lack of psychiatrists and staff to meet the needs of this group, in terms of the legal perspective, less than half of the population studied is serving a sentence so the rest of them wait for the sentence to be ratified.

Psychiatric prisoners in Tamaulipas were diagnosed primarily with psychosis, such as schizophrenia, depression, and other psychotic disorders. Furthermore, within the neurosis, prisoners with intellectual disabilities and borderline personality disorder were identified. About women within this group, they represent $5 \%$ compared to diagnosed men.

On the positive data identified, is the allocation of exclusive spaces for those diagnosed with mental illnesses. Which have spaces for sleeping, eating and recreation. In addition, visits by family and friends are common. This allows them to maintain relational networks with other people outside the prison. In addition to this, the administrative will of the CEDES allows groups such as NGOs scientific research and religious participation in recreational and research activities that help improve the quality of life of this vulnerable social group.

Pending scientific research to understand how the legal process is for these groups with the implementation of the new accusatory justice system, as well as to know the perception of the family in relation to their relatives in prison who have been psychiatrically diagnosed. And to know the perception of the members of the Technical Councils of the CEDES for the attention of these groups on the challenges and strategies used to improve the quality of life of psychiatric prisoners in Tamaulipas prisons.

\section{REFERENCES}

Alonso, J. \& Lépine, J. (2007). Overview of key data from the European Study of the Epidemiology of Mental Disorders (ESEMeD). Journal of Clinical Psychiatry. Vol. 68 (2), pp. 3-9. Available on: https://www.psychiatrist.com/JCP/article/Pages/2007/v68s02/v68s0201.aspx 
Azaola, E. (2007). The living conditions in Mexican prisons. Mexican Journal of Political and Social Sciences. Vol. 49, pp. 87-97. DOI: http://dx.doi.org/10.22201/fcpys.2448492xe.2007.200.42565

Benavides, A., Chuchuca, J., Klain, D., Waters, W., Martín, M. \& Romero, N. (2019). Depression and psychosis related to the absence of visitors and consumption of drugs in males prisoners in Ecuador: a cross sectional study. BMC Psychiatry. Vol. 19: 248. DOI: https://doi.org/10.1186/s12888-019-2227-z

Carpio, J. Vargas, C. \& Villarreal, K. (2017b). Sociofamiliar consequences of the prison in the CEDES of Reynosa Tamaulipas. Journal of History of Prisons. No. 4, pp. 93-108. Available on: http://www.revistadeprisiones.com/wp-content/uploads/2017/05/4.consecuencias.pdf

Carpio, J. Vargas, C., Hernández, I. \& Villarreal, K. (2017a). The prison life of migrants. Journal of Social
Perspectives.
Vol.
19
(2),
23
p.
Available
on:

http://perspectivassociales.uanl.mx/index.php/pers/article/view/16

Center for Public Representation (Cpr) (2013). The legal rights of prisoners with mental disorders. Empower People with disabilities. Available on: https:/www.centerforpublicrep.org/

Cerda, P. (2014). Prison and Family, challenges of social cohesion in the XXI century. Autonomous University of Nuevo León. 367 p. Available on: http://eprints.uanl.mx/12738/1/Prisi\%C3\%B3n\%20y\%20Familia.\%20ISBN.pdf

Chamizo, J. (1997). The situation of the mentally ill hospitalized in Andalusian prisons. Andalusian $\begin{array}{llll}\text { Ombudsman. } & 74 & \text { pp. Available }\end{array}$ http://www.defensordelpuebloandaluz.es/sites/default/files/txt enf mentales.pdf

Colmenares, E., Romero, M., Rodríguez, E. Durand, A. \& Saldívar, G. (2007). Female depression and substance dependence in the México city Penitentiary System. Mental Health Journal. Vol. 20 (6), pp. 53-61. Available on: https://www.medigraphic.com/pdfs/salmen/sam-2007/sam076h.pdf

Correa, G. (2016). Militarization and violence in Tamaulipas. Atlas of Security and Defense of Mexico. Casede, pp. 181-189. Available on: https://www.casede.org/PublicacionesCasede/Atlas2016/Guadalupe Correa.pdf.

Criminal Code for The State of Tamaulipas (2018). Last reform 02-11-2018. Available on: https://www.congresotamaulipas.gob.mx/LegislacionEstatal/LegislacionVigente/VerCodigo.asp?IdCo digo $=102$

Documenta. (2014). The forgotten of the forgotten: people with psychosocial disabilities in the Mexican prison system. Documenta A.C. 9 p. Available on: 
https://documenta.org.mx/layout/publicaciones/informes-justicia-discapacidad-psicosocial/informerelator-tortura-olvidados-personas-discapacidad-psicosocial-sistema-penitenciario.pdf

Early Psychosis Prevention \& Intervention Centre (Eppic) (2006). Information Sheet. 2 p. Available on: https://oyh.org.au/sites/oyh.org.au/files/factsheets/fact1 whatis.pdf

Faraldo, P. (2013). Descriptive statistics. Statistics and research methodology, Course 2012-2013. University of Santiago de Compostela. 15 p. Available on: http://eio.usc.es/eipc1/BASE/BASEMASTER/FORMULARIOS-PHPDPTO/MATERIALES/Mat G2021103104 EstadisticaTema1.pdf

Federal Criminal Code (2020). Last Reform DOF 01-24-2020. Available on: http://www.diputados.gob.mx/LeyesBiblio/pdf/9 240120.pdf

Fuentes, M. \& Fernández, E. (2016). Schizophrenia in prisons. Journal of the Spanish Association of Neuropsychiatry. Vol. 36 (130), pp. 405-420- DOI: 10.4321/S0211-57352016000200007

Guber, R. (2001). The Metropolitan Savage, Reconstruction of social knowledge in field work. Ed. Paidós, Buenos Aires. Available on: http://www.derechoshumanos.unlp.edu.ar/assets/files/documentos/elsalvaje-metropolitano.pdf

Hernández, M. \& Espinosa, J. (2000). Attention to Patients with Mental Disorders in Prisons. Journal of the Spanish Association of Neuropsychiatry. Vol. 21 (75), pp. 93-101. Available on: http://revistaaen.es/index.php/aen/article/viewFile/15734/15593

Igoumenou, A., Kallis, C. \& Coid, J. (2015). Treatment of psychosis in prisons and violent recidivism. BJPsych Open. Vol. 1 (2), pp. 149-157. DOI: 10.1192/bjpo.bp.115.000257

International Sociological Association (ISA) (2001). Ethic Code. Available on: https://www.isasociology.org/en/about-isa/code-of-

ethics\#: :text=The\%20International\%20Sociological\%20Association's\%20(ISA,sets\%20of\%20spec ific\%20Ethical\%20Standards.\&text=The\%20fact\%20that\%20a\%20particular, necessarily\%20either \%20ethical\%20or\%20unethical.

Law of Execution Sanctions of Privative and Restrictive of Liberty of the State of Tamaulipas (2012). Available on: http://po.tamaulipas.gob.mx/wpcontent/uploads/2012/08/Ley Ejecucion Sanciones.pdf

Martínez, E. (2004). Psychiatric Penitentiary? Spanish Journal of Penitentiary Health. Vol. 6, pp. 97-101. Available on: http://www.sanipe.es/OJS/index.php/RESP/article/view/274/597 
Mexico Evalua (2012). Prison in Mexico, for what? México Evalúa, Center for Public Policy Analysis. 74 p. Available on: https://www.mexicoevalua.org/wp-content/uploads/2016/05/MEX-EVA INDXCARCEL-MEXICO 10142013.pdf

Murray, C. \& Lopez, A. (1996). The Global burden of disease. Harvard University Press. 43 p. https://apps.who.int/iris/bitstream/handle/10665/41864/0965546608 eng.pdf

National Commission on Human Rights (CNDH) (2013). The situation of unimputable people with Psychosocial Disabilities in Penitentiary Centers in Mexico. Available on: http://www.cndh.org.mx/sites/all/doc/Informes/Especiales/Pronunciamiento 20160210.pdf

National Commission on Human Rights (CNDH) (2016a). Situation of uninimputable people with psychosocial disabilities in penitentiary centers of the Mexican Republic. CNDH pronouncement, 48 p. Available on: https://www.cndh.org.mx/sites/all/doc/Informes/Especiales/Pronunciamiento 20160210.pdf.

National Commission On Human RIGHTS (CNDH) (2016b). Right to Protection of the Health of Internal Persons in Penitentiary Centers of the Mexican Republic. CNDH pronouncement. 66 pp. Available on: http://www.cndh.org.mx/sites/all/doc/Informes/Especiales/Pronunciamiento 20160329.pdf

National Commission on Human Rights (CNDH) (2017). National diagnosis of prison supervision 2017. Annual Report $2017 . \quad$ Available on: https://www.cndh.org.mx/sites/all/doc/sistemas/DNSP/DNSP 2017.pdf

National Institute of Mental Health (2010). Borderline Disorder Personality. United States Department of Health and Human Services. National Institutes of Health. 27 p. Available on: http://ipsi.uprrp.edu/opp/pdf/materiales/limite personalidad.pdf

National Law of Criminal Enforcement (2016). Available on: http://www.secretariadoejecutivo.gob.mx/docs/pdfs/normateca/Leyes/Ley\%20Nacional\%20de\%20Ej ecuci\%C3\%B3n\%20Penal.pdf

Retolaza, A. (2007). Results of the ESEMeD study: Are we ready?. Northern Mental Health. Vol. 7 (29), pp. 44-50. Available on: https://dialnet.unirioja.es/servlet/articulo?codigo $=4830389$

Schalock, R., Borthwick, S., Bradley, V., Buntix, W., Coulter, M., Craig, E., Gomez, S., Lachapelle, Y., Luckasson, R., Reeve, A., Shogren, K., Snell, M., Spreat, S., Tassé, M., Thompson, J., Verdugo, M., Wehmeyer, M. And Yeager, M. (2010). Intellectual disability. Definition, Classification, and Systems of Supports. American Association on Intellectual and Developmental Disabilities. 259 p. 
Talbot, J. (2012). Fair access to Justice? Support for vulnerable defendants in the criminal courts, United Kingdom. Prison Reform Trust. 24 p. Available on: http://www.prisonreformtrust.org.uk/Portals/0/Documents/FairAccesstoJustice.pdf

Uribe, A., Martínez, A. \& Lopez, K. (2012). Depression and anxiety, state/feature among inmates assigned to the "Induction to Treatment in Prison Program" in Bucaramanga, Colombia. Criminality Journal. Vol.. 54 (2), pp. 47-60. Available on: http://www.scielo.org.co/pdf/crim/v54n2/v54n2a04.pdf

Villarreal, K. (2016). A vision of women deprived of liberty in Tamaulipas prisons. Women, Prison and Violence, K. Villarreal (Coord.). Ed Colofón, pp. 39-54.

Vos, T. \& Mathers, C. (2000). The burden of mental disorders: a comparison of methods between the Australian burden of disease studies and the Global Burden of Disease study. Bulletin of the World Health Organization, Vol. 78 (4), pp. 427-438. DOI: 10.1590/S0042-96862000000400004

World Health Organization (WHO) (2004). Invest in Mental Health. World Health Organization. 48 p. Available on: https://www.who.int/mental health/advocacy/en/spanish final.pdf

World Health Organization (WHO) (1960). Epidemiology of mental disorders: eighth report of the Committee of Experts on Mental Health. [Meeting in Geneva from June 8 to 13, 1959]. Available on:

https://apps.who.int/iris/bitstream/handle/10665/38084/WHO TRS 185 spa.pdf;jsessionid=1BE73 8DE7C26576DCD8F400D71F8A2BF? sequence $=1$

World Health Organization (WHO) (2013). Mental Health Action Plan 2013-2020. World Health Organization. 54 p. Available on: https://www.who.int/mental health/publications/action plan/es/

World Health Organization (WHO) (2017). Depression. Available on: https://www.who.int/topics/depression/es/

World Health Organization (WHO) (2018). Sustainable Health Agenda for the Americas 2018-2030. World Health Organization (WHO) and Pan American Health Organization (OPS), 60 p. Available on: http://iris.paho.org/xmlui/handle/123456789/49169

World Health Organization (WHO) (2019). Schizophrenia. Available on: https://www.who.int/es/newsroom/fact-sheets/detail/schizophrenia

Zabala, M. (2016). Prevalence of mental disorders in prison: analysis of the relationship with crimes and recidivism. Doctoral thesis by the Complutense University of Madrid, Madrid 2016. Available on: https://eprints.ucm.es/35879/1/T36874.pdf 